\title{
Intrinsic disorder in biomarkers of insulin resistance, hypoadiponectinemia, and endothelial dysfunction among the type 2 diabetic patients
}

\author{
Osama H. Al-Jiffri ${ }^{a}$, Fadwa M. Al-Sharif ${ }^{a}$, Essam H. Al-Jiffri ${ }^{a}$, and Vladimir N. Uversky ${ }^{\text {b,c,d }}$ \\ ${ }^{a}$ Department of Medical Laboratory Technology, Faculty of Applied Medical Sciences, King Abdulaziz University, Jeddah, Saudi Arabia; ${ }^{b}$ Faculty \\ of Science, Department of Biological Science, King Abdulaziz University, Jeddah, Saudi Arabia; 'Department of Molecular Medicine and USF \\ Health Byrd Alzheimer Research Institute, Morsani College of Medicine, University of South Florida, Tampa, FL, USA; ${ }^{\mathrm{d} L a b o r a t o r y}$ of Structural \\ Dynamics, Stability and Folding of Proteins, Institute of Cytology, Russian Academy of Sciences, St. Petersburg, Russia
}

\begin{abstract}
Type 2 diabetes mellitus (T2DM) is a chronic and progressive disease that is strongly associated with various complications including cardiovascular diseases and related mortality. The present study aimed to analyze the abundance and functionality of intrinsically disordered regions in several biomarkers of insulin resistance, adiponectin, and endothelial dysfunction found in the T2DM patients. In fact, in comparison to controls, obese T2DM patients are known to have significantly higher levels of inter-cellular adhesion molecule (iCAM-1), vascular cell adhesion molecule (vCAM-1), and E-selectin, whereas their adiponectin levels are relatively low. Bioinformatics analysis revealed that these selected biomarkers (iCAM-1, vCAM-1, E-selectin, and adiponectin) are characterized by the noticeable levels of intrinsic disorder propensity and high binding promiscuity, which are important features expected for proteins serving as biomarkers. Within the limit of studied groups, there is an association between insulin resistance and both hypoadiponectinemia and endothelial dysfunction.
\end{abstract}

\section{ARTICLE HISTORY}

Received 2 December 2015

Revised 15 March 2016

Accepted 17 March 2016

\section{KEYWORDS}

adiponectin; E-selectin; insulin resistance; iCAM-1; intrinsically disordered protein; Type 2 diabetes; vCAM-1

\section{Introduction}

The word-wide ubiquity of diabetes is disturbingly high and is growing. Here are just a few illustrative facts: if in the year of 2000 there were 171 million people with diabetes worldwide, this number is expected to upsurge to 366 million by $2030 .{ }^{1}$ In another study, the national levels of diabetes prevalence among adults (aged 20-79 years) of 216 countries in 2010 were evaluated and used to make a projection for $2030 .^{2}$ This analysis revealed that in 2010, the world prevalence of diabetes was $6.4 \%$ and this affliction affected 285 million adult patients, whereas by 2030 , the diabetes pervasiveness is expected to rise to $7.7 \%$ affecting 439 million adults. ${ }^{2}$ It is also expected that by 2030 , there will be $69 \%$ and $20 \%$ increase in the numbers of adults with diabetes in developing and developed countries, respectively. ${ }^{2}$

Among other health threats, type 2 diabetes mellitus (T2DM) is an important cardiovascular disease (CVD) risk factor that causes the reduction of the life expectancy ${ }^{3,4}$ and is accompanied by hypertension. ${ }^{5}$ T2DM is often associated with obesity brought about by the increased adipose tissue mass originating from the increase in the number and size of adipocytes. ${ }^{6}$ In addition, T2DM is typically associated with the reduced levels of high density lipoprotein (HDL) cholesterol (HDL-C) and is characterized by the HDL functional impairment. ${ }^{7,8}$

Being an active endocrine organ, adipose tissue is known to secrete various adipocytokines or adipokines, which are biologically active substances involved in the local and systemic regulation of numerous metabolic and inflammatory processes. ${ }^{9}$ When this endocrine function of the adipose tissue is deregulated, serious obesity-related metabolic disorders start to develop including T2DM, insulin resistance, and atherosclerosis. ${ }^{10}$

Among the variety of adipokines secreted by the adipose tissue is an important protein adiponectin, which is known to have the insulin sensitizing and

CONTACT Dr. Osama H. Al-Jiffri dr_jiffri1@outlook.com Department of Medical Laboratory Technology Faculty of Applied Medical Sciences, King Abdulaziz University, P.O. Box 80324 Jeddah, Saudi Arabia; Dr. Vladimir N. Uversky vuversky@health.usf.edu Department of Molecular Medicine, USF Health Byrd Alzheimer Research Institute, Morsani College of Medicine, University of South Florida, Tampa, FL, USA. 
anti-inflammatory activities, is able to improve systemic glucose tolerance, and has vasodilatory function protecting the vasculature from atherosclerosis. ${ }^{11}$ In the insulin-resistant humans and animals, ${ }^{12}$ as well as in obesity and in the patients with T2DM, ${ }^{13}$ the circulating levels of adiponectin are decreased. Therefore, hypoadiponectinemia is considered as an independent risk factor for T2DM and CVD development. ${ }^{14}$

Overall, there is a close association between the T2DM incidence, insulin resistance, the abnormal levels of inflammatory markers, ${ }^{13}$ and the adiponectin circulating levels. In fact, it is believed that the abnormal levels of inflammatory markers and the endothelial cell dysfunction ${ }^{15,16}$ associated with hyperlipidemia, hyperinsulinemia, and pancreatic $\beta$-cell failure ${ }^{16}$ are typical for the T2DM patients. Furthermore, endothelial dysfunction is characterized by the prothrombic properties, pro-inflammatory state, and reduced vasodilation. ${ }^{17,18}$ One of the reasons for the association between the endothelial dysfunction and insulin resistance is an essential role played by insulin in the vascular function regulation via stimulation of the expression of vascular cell adhesion molecules, such as soluble vascular cell adhesion molecule-1 (vCAM-1), soluble intercellular cell adhesion molecule-1 (iCAM1), and E-selectin on endothelium. ${ }^{19}$

Further support of the importance of adiponectin in regulation of the endothelial function is given by Lisowska et al., who found that in the angina pectoris patients undergoing coronary artery bypass grafting (CABG) the concentrations of adiponectin and cell adhesion molecule CD146 before the surgery were significantly lower than those in the control group. ${ }^{20}$ However, three months after the CABG, the adiponectin and CD146 levels were significantly increased, correlating with the concentrations of thrombomodulin, which is a natural antithrombin glycoprotein, and the well-established endothelial dysfunction marker, Von Willebrand factor. ${ }^{20}$ These findings suggested that adiponectin and CD146 can serve as markers of endothelial cell dysfunction, ${ }^{20,21}$ and that the cardiovascular system can be protected by the high adiponectin levels. However, no association between the adiponectin levels and the development of coronary artery disease was found in another study. ${ }^{22}$ To address some of these controversies, our study aimed to detect an association between insulin resistance, adiponectin, and endothelial dysfunction biomarkers and their intrinsic disorder status.
Recent studies revealed that many proteins with biologically important functions do not possess unique 3D-structures. ${ }^{23-33}$ These intrinsically disordered proteins (IDPs) and hybrid proteins containing both ordered and intrinsically disordered domains/ regions $^{34}$ are very common in nature, ${ }^{31,35-39}$ with IDPs constituting significant fractions of all known proteomes, ${ }^{31,35,36,40,41}$ and therefore being considered now as an important extension of the protein kingdom. ${ }^{23,28,32,42-46}$ Despite their lack of unique 3Dstructures, these proteins are involved in crucial biological processes (such as signaling, regulation, and recognition), ${ }^{23-29,31,42,47-58}$ and their functions complement the functional repertoire of the ordered proteins. ${ }^{55-57}$ Furthermore, being general regulators and controllers, many IDPs are intimately associated with the variety of human diseases. ${ }^{59,60}$ Since earlier study revealed that proteins related to CVD are enriched in intrinsic disorder, ${ }^{61}$ and since T2DM is an important CVD risk factor, we analyzed the intrinsic disorder propensity and the presence of disorderbased functional sites in the biomarkers utilized in this study (human adiponectin, iCAM-1, vCAM-1, and E-selectin) by a series of bioinformatics tools.

\section{Materials and methods}

\section{Computational analyses of the amino acid sequences of biomarkers}

Amino acid sequences of four human proteins utilized as biomarkers, adiponectin (UniProt ID: Q15848), inter-cellular adhesion molecule (iCAM-1, UniProt ID: P05362), vascular cell adhesion molecule (vCAM1, UniProt ID: P19320), and E-selectin (UniProt ID: P16581) were downloaded from UniProt (http://www. uniprot.org/uniprot/). The intrinsic disorder propensities of these biomarkers were evaluated by several per-residues disorder predictors, such as $\mathrm{PONDR}^{\circledR}$

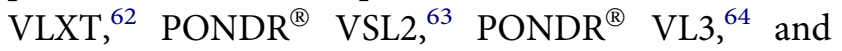
PONDR $^{\circledR}$ FIT, $^{65}$ which were chosen based on their different sensitivities to the various protein intrinsic disorder-related features. PONDR ${ }^{\circledR}$ VSL2B is one of the more accurate stand-alone disorder predictors, ${ }^{63,66,67}$ PONDR $^{\circledR}$ VLXT is known to have high sensitivity to local sequence peculiarities and can be used for identifying disorder-based interaction sites, ${ }^{62}$ whereas a metapredictor PONDR-FIT ${ }^{65}$ is moderately more accurate than each of its component predictors, 
PONDR $^{\circledR} \quad$ VLXT $^{62}{ }^{6}$ PONDR $^{\circledR}$ VSL2, ${ }^{63}$ PONDR $^{\circledR}$ VL3,${ }^{64}$ FoldIndex ${ }^{68}$ and IUPred. ${ }^{69}$

The $\mathrm{D}^{2} \mathrm{P}^{2}$ internet database, ${ }^{70}$ which is a community resource for the pre-computed disorder predictions on a large library of proteins from completely sequenced genomes (http://d2p2.pro/) was used to provide more information on the presence of functional disordered regions in the query proteins. As the measure of disorder predisposition, $\mathrm{D}^{2} \mathrm{P}^{2}$ database uses outputs of PONDR $^{\circledR}$ VLXT, $^{62}$ IUPred, ${ }^{69}$ PONDR $^{\circledR}$ VSL2B $^{71,72}$ PrDOS, $^{73}$ ESpritz $^{74}$ and PV2. ${ }^{70}$ This database is further enhanced by the information on the curated sites of various posttranslational modifications and on the location of predicted disorderbased potential binding sites.

Finally, the interactivity of biomarkers used in this study was further evaluated by STRING (Search Tool for the Retrieval of Interacting Genes) database, which is the online resource that provides both experimental and predicted interaction information for query proteins. ${ }^{75}$

\section{Results}

As it follows from literature data and our own results (data not shown) in comparison with controls, T2DM patients typically show significantly higher levels of iCAM-1, vCAM-1, and E-selectin, whereas their adiponectin levels are significantly lower than those of the matched controls. To check the intrinsic disorder status of the biomarkers used in our study, we evaluated the disorder propensities of human adiponectin, iCAM-1, vCAM-1, and Eselectin by several per-residues disorder predictors. Results of this analysis are summarized in Figure 1, which clearly shows that the N-terminal half of adiponectin is predicted to be highly disordered, and that all other biomarkers contain substantial amounts of disorder, mostly in the form of short disordered regions.

Next, the disorder predispositions of these proteins were analyzed by the $\mathrm{D}^{2} \mathrm{P}^{2}$ database. ${ }^{70}$ Figure 2 represents the results of this analysis and confirms that

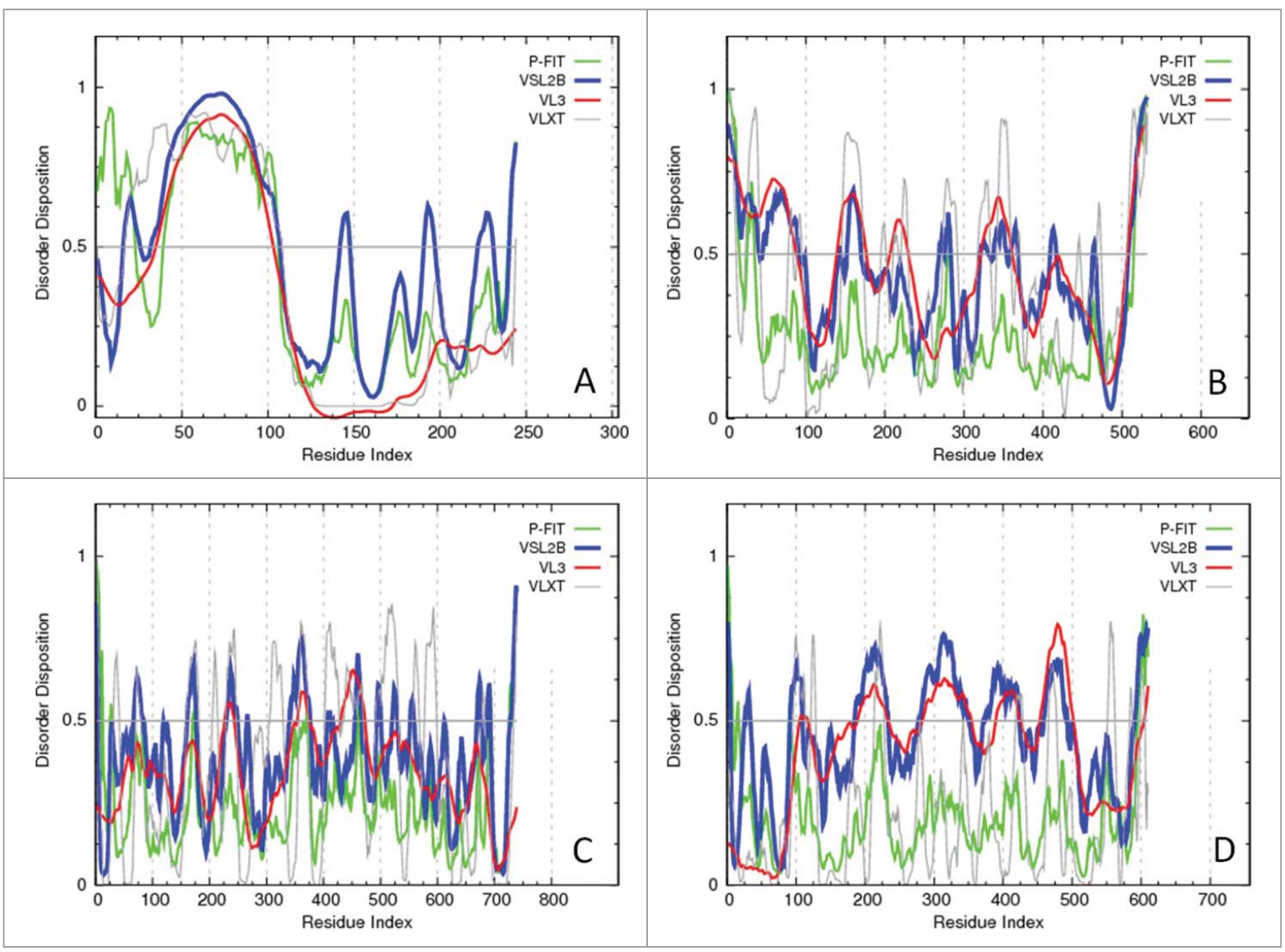

Figure 1. Evaluating the intrinsic disorder propensities of the human adiponectin (UniProt ID: Q15848; A), iCAM-1 (UniProt ID: P05362; B), vCAM-1 (UniProt ID: P19320; C), and E-selectin (UniProt ID: P16581; D) by the family of PONDR predictors. A disorder threshold is indicated as a thin line (at score $=0.5$ ) in all plots to show a boundary between disorder $(>0.5)$ and order $(<0.5)$. 


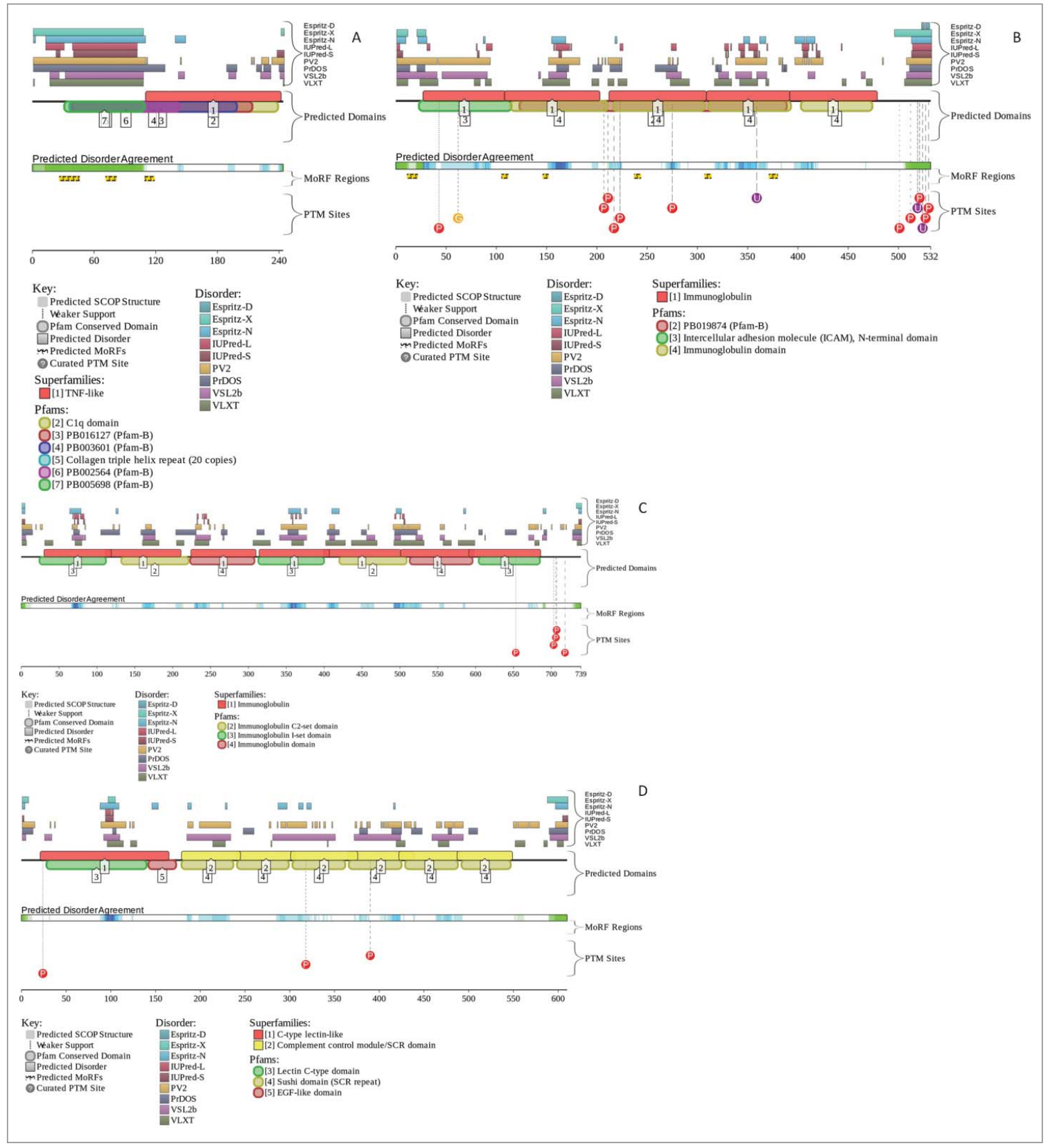

Figure 2. Evaluation of the functional intrinsic disorder propensity of the human adiponectin (UniProt ID: Q15848; A), iCAM-1 (UniProt ID: P05362; B), vCAM-1 (UniProt ID: P19320; C), and E-selectin (UniProt ID: P16581; D) by the D P $^{2}$ platform (http://d2p2.pro/). ${ }^{70}$ In this plot, top nine colored bars represent location of disordered regions predicted by different computational tools (Espritz-D, Espritz-N, Espritz-X, IUPred-L, IUPred-S, PV2, PrDOS, PONDR ${ }^{\circledR}$ VSL2b, and PONDR ${ }^{\circledR}$ VLXT, see keys for the corresponding color codes). Dark red bar shows the location of the functional domain found by the Pfam platform, which is a database of protein families that includes their annotations and multiple sequence alignments generated using hidden Markov models. ${ }^{137-139}$ Green-and-white bar in the middle of the plot shows the predicted disorder agreement between these nine predictors, with green parts corresponding to disordered regions by consensus. Red, yellow and purple circles at the bottom of the plot show the locations of phosphorylation, acetylation and ubiquitination sites, respectively.

human adiponectin, iCAM-1, vCAM-1, and E-selectin all possess functional disordered regions containing potential phosphorylation and protein-protein interaction sites. These observations are in agreement with the well-known fact that phosphorylation sites ${ }^{76}$ and sites of various posttranslational modifications
(PTMs) are preferentially located within the intrinsically disordered regions. ${ }^{77}$

Finally, Figure 3 represents the outputs of the STRING online computational platform ${ }^{75}$ that illustrate the interactability of human adiponectin, iCAM1, vCAM-1, and E-selectin and shows that these 


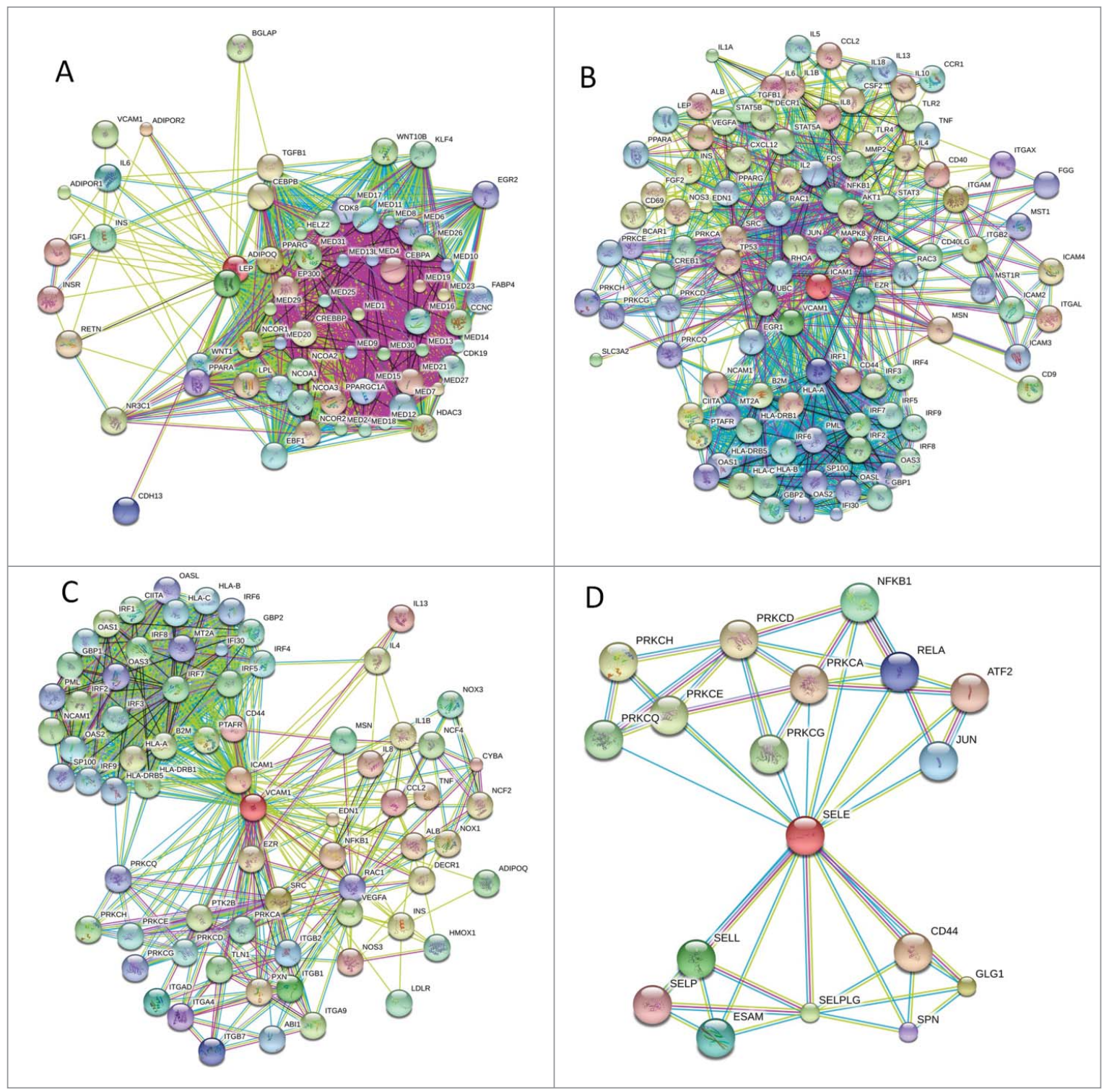

Figure 3. Analysis of the interactivity of the human adiponectin (UniProt ID: Q15848; A), iCAM-1 (UniProt ID: P05362; B), vCAM-1 (UniProt ID: P19320; C), and E-selectin (UniProt ID: P16581; D) by STRING. ${ }^{75}$ STRING produces the network of predicted associations for a particular group of proteins. The network nodes are proteins, whereas the edges represent the predicted or known functional associations. An edge may be drawn with up to 7 differently colored lines that represent the existence of the seven types of evidence used in predicting the associations. A red line indicates the presence of fusion evidence; a green line - neighborhood evidence; a blue line - co-occurrence evidence; a purple line - experimental evidence; a yellow line - text mining evidence; a light blue line - database evidence; a black line - co-expression evidence. ${ }^{75}$

biomarkers are characterized by high binding promiscuity.

It is important to note here that the intrinsic disorder propensities described here for the T2DM biomarkers might have significant functional implementations. In fact, some previous studies do indicate the potential roles of intrinsically disordered regions in functionality of these proteins and in their involvement into pathogenesis. For example, based on the $\mathrm{PONDR}^{\circledR}$ VSL2 analysis, human adiponectin
(UniProt ID: Q15848) is predicted to have the average disorder score of 0.477 and have 6 disordered regions that include $45.9 \%$ of all its residues. Structurally, adiponectin can be divided into the $\mathrm{N}$-terminal variable region (residues 19-41), the collagenous domain (residues 42-107), and the C-terminal globular domain (residues 108-244). ${ }^{78,79}$ This protein in known to exist in various oligomeric forms including a trimer, a hexamer and larger order multimeric forms collectively known as high molecular weight multimers 
(HMW) ${ }^{80}$ Formation of trimers is driven by the hydrophobic interactions among the globular domains and a propensity of the collagenous domains to form the triple helical structure, ${ }^{78,81,82}$ whereas multimers larger than a trimer are stabilized by a disulfide bond between two trimers via a conserved $\mathrm{Cys}_{22}$ residue in the variable region, ${ }^{80,83}$ and the formation of HMW multimers larger than a hexamer requires specific post-translational modifications (PTMs). ${ }^{84}$ Furthermore, G84R and G90S mutants of adiponectin that cannot form HMW multimers are known to be associated with diabetes and hypoadiponectinemia. ${ }^{80}$ Noticeably, the multimerization-promoting PTMs (e.g., glycosylation sites at $\mathrm{Lys}_{68}, \mathrm{Lys}_{71}, \mathrm{Lys}_{80}$, and Lys $_{104}$, and hydroxylation on $\mathrm{Pro}_{71}, \mathrm{Pro}_{76}$, and Pro ${ }_{95}$ ) and multimerization-inhibiting mutations are all located within the $\mathrm{N}$-terminal half of adiponectin that contains the N-terminal variable region and the collagenous domain and is predicted to be mostly disordered in our study (see Figs. 1 and 2). In our view, these observations provide a direct link between the intrinsically disordered nature of the N-terminal domain of adiponectin and the role of this protein in diabetes and hypoadiponectinemia. Finding of the significant amounts of disorder in collagenous domain of adiponectin is in agreement with earlier studies, where very high levels of disorder were found in various extracellular matrix proteins and in collegens. ${ }^{85,86}$

Human E-selectin (UniProt ID: P16581) is predicted by PONDR ${ }^{\circledR}$ VSL2 to have $42.0 \%$ disordered residues, 8 disordered regions, and the average disorder score of 0.456 . This protein possesses an N-terminal $\mathrm{Ca}^{2+}$-dependent lectin domain (residues 22-139), an epidermal growth factor (EGF)-like domain (residues 140-175), six consensus repeat units, Sushi domains, also known as Complement control protein (CCP) modules, or short consensus repeats (SCR) (residues 178-239, 240-301, 303-364, 366-427, 429490, and 491-549), a transmembrane (TM) domain (residues 557-578), and an intracellular cytoplasmic C-tail (residues 579-610). Functional analysis showed that the short consensus repeat (SCR) domains are needed for the efficient interaction of this protein with its ligand that that all six SCR domains play a role in blocking neutrophil or HL-60 cell adhesion to E-selectin. ${ }^{87}$ Figures 1 and 2 shows that there are several disordered regions in E-selectin (e.g., according to the PONDR $^{\circledR}$ VSL2 analysis, this protein has five relatively long disordered regions, residues 185-233, 281-
$350,372-423,459-493$, and 584-610) that cover significant portions of functional Sushi domains and the cytoplasmic C-tail.

According to the PONDR ${ }^{\circledR}$ VSL2 analysis, human iCAM-1 (UniProt ID: P19320) is predicted to have $36.1 \%$ disordered residues assembled into 11 disordered regions and have an average disorder score of 0.443. Besides a transmembrane spanning region (residues 481-503) and a short cytoplasmic domain (residues 504-532), there are five extracellular Ig-like C2-type domains (D1-D5) in human iCAM-1 (residues 41-103, 128-193, 230-297, 325-378, and 412464). Figures $1 \mathrm{~B}$ and $2 \mathrm{~B}$ show that although each of these IG-like domains is expected to have significant levels of intrinsic disorder, their intrinsic disorder propensities are not identical. In fact, domains D1 and D4 are predicted to have the most disordered residues followed by domain D2, and with domains D3 and D5 possessing least amount of disorder. The Ig-like domains are known to have different functions. For example, D1 serves as the binding site for the integrin lymphocyte function-associated antigen-1 (LFA-1) and human rhinovirus, ${ }^{88}$ whereas D3 binds to the Mac-1 integrin. ${ }^{89}$ Human iCAM-1 is predicted to have 6 disorder-based potential binding sites (molecular recognition features, MoRFs) and a highly disordered cytoplasmic C-tail, which is heavily decorated with multiple PTMs. Furthermore, domains D2, D3, and D4 of iCAM-1 were shown to contain a number of N-linked glycan chains that contribute to stability and function of this protein. ${ }^{90-92}$ Known glycosylation sites (GlcNAc residues) are located at positions 130 (0.285), 145 (0.470), 183 (0.441), 202 (0.454), 260 (0.333), 267 (0.460), 296 (0.306), 385 (0.359), and 406 (0.414) and are characterized by relatively large disorder scores (numbers shown in brackets), suggesting that all these sites are located within the flexible regions. Curiously, in agreement with our finding that D1 is expected to be one of the most disordered domains of iCAM-1, it was shown that this domain cannot fold on its own likely because of the loss of its interaction with the second domain. ${ }^{88}$

Although Figures 1 and 2 show that human vCAM1 (UniProt ID: P19320) is predicted to be the most ordered of the T2DM biomarkers analyzed in our study, this protein has several disordered and flexible regions characterized by the disorder scores exceeding 0.5 and 0.3 , respectively. In fact, according to the PONDR $^{\circledR}$ VSL2 analysis, this protein has an average 
disorder score of 0.384 and contains $22.1 \%$ disordered residues assembled into 16 relatively short disordered regions. There are seven extracellular, Ig-like C2-type domains in this protein (residues 25-105, 109-212, 223-309, 312-399, 408-506, 511-595, and 600-684), C-terminally located transmembrane region (residues 699-720) and a very short cytoplasmic C-tail (residues 721-739). Importantly, almost all linkers between these domains are predicted to be disordered or flexible. Furthermore, intrinsic disorder propensities of individual Ig-like C2-type domains are not even, with three of these domains (residues 312-399, 408-506 and 511-595) being definitely more disordered than their counterparts (see Figs. 1C and 2C). It is known that vCAM-1 can be found in three isoforms produced by alternative splicing, where isoforms 2 and 3 differ from the canonical isoform shown in Figure 1C and $2 \mathrm{C}$ by missing the $310-402$ (which is substituted by a single alanine residue) and 52-113 regions, respectively. In agreement with earlier study showing that the mRNA regions affected by alternative splicing are significantly biased toward encoding disordered residues, ${ }^{93}$ these two regions of vCAM-1 removed by alternative splicing are predicted to contain significant levels of disorder.

\section{Discussion}

The hyperglycemia caused in T2DM by the insulin resistance can eventually cause the development of a multitude of the micro- and macrovascular complications. As a result, in comparison with healthy controls, the T2DM patients experience two to four times higher risk of the development of coronary artery disease, ${ }^{94}$ peripheral vascular disease, ${ }^{95}$ and cerebrovascular disease. ${ }^{96}$ Furthermore, CVD-related mortality among the patients with T2DM may be up to four times higher than that seeing in the background population. ${ }^{97}$ It is known that insulin resistance and its manifestations precede T2DM and its cardiovascular complications and therefore can be used to predict these maladies. ${ }^{98}$ Furthermore, there is an association between the insulin resistance characterizing the obese subjects and the endothelial dysfunction. ${ }^{99,100}$ Also, the obese individuals are characterized by the down regulation of an important circulating adipose tissuederived hormone, adiponectin. ${ }^{101}$ Experimental studies show that adiponectin may protect against the development of insulin resistance, atherosclerosis, and inflammation. ${ }^{102}$

Therefore, it is likely that the obese T2DM patients have insulin resistance and are characterized by the reduction of the adiponectin levels and alterations in the levels of the endothelial function biomarkers. This hypothesis is in agreement with the work by Meigs et al., who reported that the endothelial dysfunction can be used to predict T2DM among women. ${ }^{103}$ Also, Thorand et al. supported the role of the endothelial dysfunction in the T2DM pathogenesis. ${ }^{104}$ The levels of soluble E-selectin were independently found to be associated with diabetes. ${ }^{105,106}$ In addition, the Women's Health Initiative Observational Study proved that the E-selectin levels could be considered as a predictor of diabetes among the USA women. ${ }^{107}$ The decreased adiponectin levels among the obese T2DM patients could be due to the decreased adiponectin production by the enlarged adipocytes in the states of increased adiposity, since adiponectin is predominantly secreted by the pre-adipocytes. ${ }^{108}$ One of the mechanisms for the negative correlation between the adiposity and adiponectin levels might be the increased secretion of TNF- $\alpha$ (TNF- $\alpha$ ) from the accumulated visceral fat which potentially inhibits adiponectin secretion. ${ }^{109-111}$

A study conducted by Vaverkova et al. independently found a positive association of soluble vCAM-1 with adiponectin. ${ }^{112}$ In another study of the high risk dyslipidemic patients, these authors found altered levels of these biomarkers in the patients with vascular disease or dyslipidemia. ${ }^{113}$ The existence of the positive association between the soluble vCAM-1 and adiponectin was also recently described in T2DM patients with diabetic nephropathy and was associated with the endothelial dysfunction measured by the flow-mediated dilatation. ${ }^{114}$

The association between the insulin resistance and the endothelial dysfunction can be explained by the decreased dihydropterin reductase activity caused by the insulin resistance with the subsequent depletion of an essential cofactor of the catalytic activity of nitric oxide synthase (NOS), the tetrahydrobiopterin (BH4). ${ }^{115}$ This BH4 depletion might lead to the increased levels of the oxidative stress and endothelial dysfunction. ${ }^{115}$ In agreement with the observations that insulin can serve as a vasodilator and stimulate endothelial nitric oxide (NO) production, ${ }^{116,117}$ several studies have demonstrated that the T2DM patients might be characterized by the abnormal NO-mediated 
vasodilation. ${ }^{118}$ In the same way as insulin resistance may contribute to the endothelial dysfunction, the defects in the NO-mediated vasodilation may contribute to the insulin resistance. ${ }^{119}$

Another possible mechanism of the endothelial dysfunction induced by insulin resistance is based on the impaired ability of insulin to inhibit very low density lipoprotein (VLDL) production in the liver of the T2DN patients. ${ }^{120}$ An increase in serum triglycerides is accompanied by generation of small dense low density lipoprotein (LDL) particles that also contributes to the endothelial dysfunction in patients with type 2 diabetes. ${ }^{121}$

The association between the insulin resistance and the hypoadiponectinemia can be due to the effects of high blood levels of glucose and fatty acids. High blood levels of fatty acids are the direct cause of the insulin resistance. According to Dresner et al. ${ }^{122}$ and Griffin et al., ${ }^{123}$ an increase in the delivery of fatty acids to the muscles or a decrease in the intracellular metabolism of fatty acids might lead to the accumulation of the intracellular fatty acid metabolites, such as diacylglycerol, fatty acyl CoA, and ceramides. These metabolytes activate a serine/threonine kinase cascade leading to the phosphorylation of serine and threonine sites of the insulin receptor substrate 1 (IRS1) and the insulin receptor substrate 2 (IRS2). This, in turn, reduces the ability of these IRS1 and IRS2 to activate phosphatidylinositol 3 kinase (PI 3 kinase) and eventually leads to the reduced activity of the glucose transporter 4 (GLUT4). ${ }^{122,123}$ As a consequence, the glucose uptake in the skeletal muscle cells is reduced because the diminished glucose transport activity of the insulin receptors. The decrease in the levels of plasma adiponectin can cause the decreased glucose uptake, increased gluconeogenesis, and decreased fatty acid oxidation in the skeletal muscles and the liver. The decrease in the oxidation of fatty acids defines the increase in the levels of free fatty acids, followed by the increase in the insulin resistance, and finally leading to the decrease in the glucose uptake. ${ }^{122,123}$ The decrease in the glucose uptake and the increase in the gluconeogenesis ultimately result in the increase in the levels of plasma glucose leading to T2DM. ${ }^{124}$

Four biomarkers used in our study clearly belong to the class of multitasking proteins which often rely on intrinsic disorder for their multifunctionality. For example, adiponectin is a unique and abundant protein hormone that serves as an adipokine responsible for the modulation of numerous metabolic processes, such as glucose regulation and fatty acid catabolism. ${ }^{125,126}$ At least four major biological functions were ascribed to adiponectin, regulation of metabolism, vascular protection, anti-inflammatory response, and cardioprotection/anti-ischemic function. ${ }^{126,127} \mathrm{In}$ these functions, adiponectin regulates metabolism by participating in the increase in the insulin sensitivity, glucose utilization, and fatty acid oxidation. The vascular protective function is based on the adiponectin's roles in the enhancement of the NO production and the angiogenesis stimulation, whereas its anti-inflammatory role relies on the decrease in both neutrophil adhesion and macrophage activation. ${ }^{127}$ Human adiponectin has 244 residues and includes a signal peptide (residues 1-18) that targets adiponectin for extracellular section and is cleaved in the mature protein, a non-conserved N-terminal region (residues 1941) followed by the collagen-like domain (residues 42-107), and a C-terminal globular domain (residues 108-244). Structurally, this C-terminal globular domain of human adiponectin is similar to TNF- $\alpha$, despite dissimilar amino acid sequences. ${ }^{126}$ In agreement with the results of our computational analysis, biological activities of the full-length adiponectin are known to be controlled by numerous post-translational modifications (e.g., hydroxylation and glycosylation). The adipocyte-secreted adiponectin exists in three forms, trimers ( $\sim 90 \mathrm{kDa}$; the basic unit), lowmolecular-weight hexamers $(\sim 180 \mathrm{kDa})$, and highmolecular-weight isoforms consisting of 12-mers to 18-mers (which can exceed $400 \mathrm{kDa}$ ). ${ }^{126}$ Again, in agreement with our bioinformatics analysis, monomeric adiponectin is thermodynamically unstable and has not been observed under native conditions, whereas its proteolytic cleavage product containing globular C-terminal domain has been postulated to exist in vivo. ${ }^{126}$ Curiously, the Arg112Cys and Ile164Thr mutations that prevent adiponectin from trimer formation and result in the impaired secretion of this protein from the cell were shown to be clinically associated with hypoadiponectinemia. ${ }^{80}$

Intercellular cell adhesion molecule-1 (iCAM-1), also known as CD54 (cluster of differentiation 54), is an immunoglobulin-like glycoprotein expressed on the surface of several cell types including endothelial cells and cells involved in the immune response, ${ }^{128}$ where it serves as a ligand for the leukocyte adhesion protein LFA-1 (integrin $\alpha-\mathrm{L} / \beta-2)$. Besides its major role in stabilizing cell-cell 
interactions and facilitating leukocyte endothelial transmigration, iCAM-1 serves as a site for the cellular entry of human rhinovirus ${ }^{129,130}$ and is involved in a signal transduction ${ }^{131}$ and spermatogenesis. ${ }^{132}$ Human iCAM-1 has a signal peptide (residues 1-27) and is known to exist in the membrane-bound and soluble forms, with the transmembrane form possessing a large N-terminal extracellular domain (residues 28-480), a single-span transmembrane region (residues 481-503), and a small C-terminal cytoplasmic domain (residues 504-532). Human iCAM-1 is a heavily glycosylated and phosphorylated protein, with the extracellular domain being composed of multiple loops stabilized by seven disulfide bonds (Cys48-Cys92, Cys52Cys96, Cys135-186, Cys237-290, Cys332-Cys371, Cys403-Cys419, and Cys431-Cys457). Curiously, many of these loops correspond to the regions predicted to be disordered in our study.

Vascular cell adhesion molecule-1 (vCAM-1), also known as cluster of differentiation 106 (CD106), is an important cell adhesion protein mediating the adhesion of the components of the immune system (such as lymphocytes, monocytes, eosinophils, and basophils) to vascular endothelium. ${ }^{133,134}$ It also functions in leukocyte-endothelial cell signal transduction, it may play a role in the development of atherosclerosis, and rheumatoid arthritis, and may be used by tumor cells to escape T-cell immunity. ${ }^{134}$ Organization of vCAM-1 is very similar to that of iCAM-1, and human CD106 has a signal peptide (residues 1-24), a large Nterminal extracellular domain (residues 25-698), a single-span transmembrane region (residues 699720), and a short C-terminal cytoplasmic domain (residues 721-739). The protein is glycosylated at multiple sites and has several disulfide bond-stabilized loops (Cys47-Cys95, Cys52-Cys99, Cys137-195, Cys246291, Cys335-Cys383, and Cys534-Cys579). Similar to iCAM-1, many of these loops are predicted to contain significant amounts of disorder.

Finally, E-selectin, also known as cluster of differentiation 62 (CD62) antigen-like family member E (CD62E), endotheliaL-leukocyte adhesion molecule 1 (ELAM-1), or leukocyte-endothelial cell adhesion molecule 2 (LECAM2), is a cell adhesion protein expressed only by the cytokine-activated endothelial cells. ${ }^{135}$ E-selectin plays a role in immunoadhesion by mediating the adhesion of blood neutrophils in cytokine-activated endothelium through interaction with PSGL1/SELPLG. ${ }^{136}$ Since E-selectin is a typical adhesin, its topological structure, being similar to those of
iCAM-1 and vCAM-1, includes a signal peptide (residues 1-21), a large $\mathrm{N}$-terminal extracellular domain (residues 22-556) that contains C-type lectin domain (residues 22-139), an EGF (epidermal-growth-factor)like domain (residues 140-175), six Sushi domain (SCR repeat) units (residues 178-249, 240-301, 303364, 366-427, 429-490, and 491-549), a single-span transmembrane region (residues 557-578), and a short C-terminal cytoplasmic tail (residues 579-610). There are several glycosylation and phosphorylation sites in human E-selecting, and this protein is heavily cross-linked by 16 disulfide bridges (Cys40-Cys138, Cys111-Cys130, Cys143-154, Cys148-163, Cys164Cys174, Cys210-Cys237, Cys242-Cys286, Cys272Cys299, Cys304-349, Cys335-362, Cys367-Cys412, Cys398-Cys425, Cys430-Cys475, Cys461-Cys488, Cys493-534, and Cys520-Cys547). Since E-selectin is predicted to be noticeably more disordered than the iCAM-1 and vCAM-1 (the content of the PONDR ${ }^{\circledR}$ VSL2-predicted disordered residues in E-selectin is 42.0\%, whereas iCAM-1 and VCAM-1 contain 36.1\% and $35.3 \%$ disordered residues, respectively), it is likely that the larger number of disulfide bonds and their more complex pattern are needed to keep the structure of this protein stable.

\section{Conclusions}

There is an association between insulin resistance and both hypoadiponectinemia and endothelial dysfunction, and proteins used as biomarkers to emphasize these connections are predicted to contain substantial amount if intrinsic disorder. The elevated disorder content in these important proteins might explain their exceptional multifunctionality.

\section{Disclosure of potential conflicts of interest}

No potential conflicts of interest were disclosed.

\section{Author contributions}

O.H.A. wrote the manuscript and analyzed data. F.A.M. analyzed data and contributed to discussion. E.H.A. contributed to discussion and reviewed/edited manuscript. V.N.U. analyzed data, contributed to discussion, and wrote the manuscript.

\section{References}

[1] Wild S, Roglic G, Green A, Sicree R, King H. Global prevalence of diabetes: estimates for the year 2000 and projections for 2030. Diabetes Care 2004; 27:1047-53; 
PMID:15111519; $\quad$ http://dx.doi.org/10.2337/diacare. 27.5.1047

[2] Shaw JE, Sicree RA, Zimmet PZ. Global estimates of the prevalence of diabetes for 2010 and 2030. Diabetes Res Clin Pract 2010; 87:4-14; PMID:19896746; http://dx.doi. org/10.1016/j.diabres.2009.10.007

[3] Leiter LA, Fitchett DH, Gilbert RE, Gupta M, Mancini GB, McFarlane PA, Ross R, Teoh H, Verma S, Anand S, et al. Identification and management of cardiometabolic risk in Canada: a position paper by the cardiometabolic risk working group (executive summary). Can J Cardiol 2011; 27:124-31; PMID:21459258; http://dx.doi.org/ 10.1016/j.cjca.2011.01.016

[4] Seshasai SR, Kaptoge S, Thompson A, Di Angelantonio E, Gao P, Sarwar N, Whincup PH, Mukamal KJ, Gillum RF, Holme I, et al. Diabetes mellitus, fasting glucose, and risk of cause-specific death. N Engl J Med 2011; 364:829-41; PMID:21366474; http://dx.doi.org/10.1056/ NEJMoa 1008862

[5] Chen G, McAlister FA, Walker RL, Hemmelgarn BR, Campbell NR. Cardiovascular outcomes in framingham participants with diabetes: the importance of blood pressure. Hypertension 2012; 57:891-7; http://dx.doi. org/10.1161/HYPERTENSIONAHA.110.162446

[6] DeFronzo RA. Insulin resistance, lipotoxicity, type 2 diabetes and atherosclerosis: the missing links. The Claude Bernard Lecture 2009. Diabetologia 2010; 53:1270-87; PMID:20361178; http://dx.doi.org/10.1007/ s00125-010-1684-1

[7] Besler C, Luscher TF, Landmesser U. Molecular mechanisms of vascular effects of High-density lipoprotein: alterations in cardiovascular disease. EMBO Mol Med 2012; 4:251-68; PMID:22431312; http://dx.doi.org/ $10.1002 / \mathrm{emmm} .201200224$

[8] Farbstein D, Levy AP. HDL dysfunction in diabetes: causes and possible treatments. Expert Rev Cardiovasc Ther 2012; 10:353-61; PMID:22390807; http://dx.doi. org/10.1586/erc.11.182

[9] Greenberg AS, Obin MS. Obesity and the role of adipose tissue in inflammation and metabolism. Am J Clin Nutr 2006; 83:461S-5S; PMID:16470013.

[10] Murdolo G, Smith U. The dysregulated adipose tissue: a connecting link between insulin resistance, type 2 diabetes mellitus and atherosclerosis. Nutr Metab Cardiovasc Dis 2006; 16 Suppl 1:S35-8; http://dx.doi.org/10.1016/j. numecd.2005.10.016

[11] Li FY, Cheng KK, Lam KS, Vanhoutte PM, Xu A. Crosstalk between adipose tissue and vasculature: role of adiponectin. Acta Physiol (Oxf) 2011; 203:167-80; PMID:21062420; http://dx.doi.org/10.1111/j.1748-1716. 2010.02216.x

[12] Zhao L, Fu Z, Liu Z. Adiponectin and insulin cross talk: the microvascular connection. Trends Cardiovasc Med 2014; 24:319-24; PMID:25220977; http://dx.doi.org/ 10.1016/j.tcm.2014.08.001

[13] Ndumele CE, Pradhan AD, Ridker PM. Interrelationships between inflammation, C-reactive protein, and insulin resistance. J Cardiometab Syndr 2006; 1:190-6; PMID:17679826; http://dx.doi.org/10.1111/j.15594564.2006.05538.x

[14] Misu H, Ishikura K, Kurita S, Takeshita Y, Ota T, Saito Y, Takahashi K, Kaneko S, Takamura T. Inverse correlation between serum levels of selenoprotein $\mathrm{P}$ and adiponectin in patients with type 2 diabetes. PLoS One 2012; 7:e34952; PMID:22496878; http://dx.doi.org/10.1371/ journal.pone.0034952

[15] Gomez JM, Vila R, Catalina P, Soler J, Badimon L, Sahun M. The markers of inflammation and endothelial dysfunction in correlation with glycated haemoglobin are present in type 2 diabetes mellitus patients but not in their relatives. Glycoconj J 2008; 25:573-9; PMID:18347976; http://dx.doi. org/10.1007/s10719-008-9118-8

[16] Ansar S, Koska J, Reaven PD. Postprandial hyperlipidemia, endothelial dysfunction and cardiovascular risk: focus on incretins. Cardiovasc Diabetol 2011; 10:61; PMID: 21736746; http://dx.doi.org/10.1186/1475-2840-10-61

[17] Endemann DH, Schiffrin EL. Endothelial dysfunction. J Am Soc Nephrol 2004; 15:1983-92; PMID:15284284; http://dx.doi.org/10.1097/01.ASN.0000132474.50966.DA

[18] Gomez JM, Sahun M, Vila R, Domenech P, Catalina P, Soler J, Badimon L. Elevation of E-selectin concentrations may correlate with potential endothelial dysfunction in individuals with hypopituitarism during therapy with growth hormone. Curr Neurovasc Res 2007; 4:5562; PMID:17311545; http://dx.doi.org/10.2174/ 156720207779940662

[19] Cersosimo E, DeFronzo RA. Insulin resistance and endothelial dysfunction: the road map to cardiovascular diseases. Diabetes Metab Res Rev 2006; 22:423-36; PMID:16506274; http://dx.doi.org/10.1002/dmrr.634

[20] Lisowska A, Lisowski P, Knapp M, Tycinska A, Sawicki R, Malyszko J, Hirnle T, Musial WJ. Serum adiponectin and markers of endothelial dysfunction in stable angina pectoris patients undergoing coronary artery bypass grafting (CABG). Adv Med Sci 2014; 59:245-9; PMID:25108276; http://dx.doi.org/10.1016/j.advms. 2014.05.001

[21] Saito T, Saito O, Kawano T, Tamemoto H, Kusano E, Kawakami M, Ishikawa SE. Elevation of serum adiponectin and CD146 levels in diabetic nephropathy. Diabetes Res Clin Pract 2007; 78:85-92; PMID:17490776; http://dx.doi.org/10.1016/j.diabres.2007.02.014

[22] Lindsay RS, Resnick HE, Zhu J, Tun ML, Howard BV, Zhang Y, Yeh J, Best LG. Adiponectin and coronary heart disease: the Strong Heart Study. Arterioscler Thromb Vasc Biol 2005; 25:e15-6; PMID:15731480; http://dx.doi.org/10.1161/01.ATV.0000153090.21990.8c

[23] Wright PE, Dyson HJ. Intrinsically unstructured proteins: re-assessing the protein structure-function paradigm. J Mol Biol 1999; 293:321-31; PMID:10550212; http://dx.doi.org/10.1006/jmbi.1999.3110

[24] Uversky VN, Gillespie JR, Fink AL. Why are "natively unfolded" proteins unstructured under physiologic conditions? Proteins 2000; 41:415-27; PMID:11025552; 
http://dx.doi.org/10.1002/1097-0134(20001115)41:3<415:: AID-PROT130>3.0.CO;2-7

[25] Dunker AK, Lawson JD, Brown CJ, Williams RM, Romero P, Oh JS, Oldfield CJ, Campen AM, Ratliff CM, Hipps KW, et al. Intrinsically disordered protein. J Mol Graph Model 2001; 19:26-59; PMID:11381529; http:// dx.doi.org/10.1016/S1093-3263(00)00138-8

[26] Tompa P. Intrinsically unstructured proteins. Trends Biochem Sci 2002; 27:527-33; PMID:12368089; http:// dx.doi.org/10.1016/S0968-0004(02)02169-2

[27] Uversky VN. What does it mean to be natively unfolded? Eur J Biochem 2002; 269:2-12; PMID:11784292; http://dx. doi.org/10.1046/j.0014-2956.2001.02649.x

[28] Uversky VN. Natively unfolded proteins: a point where biology waits for physics. Protein Sci 2002; 11:739-56; PMID:11910019; http://dx.doi.org/10.1110/ps.4210102

[29] Dyson HJ, Wright PE. Intrinsically unstructured proteins and their functions. Nat Rev Mol Cell Biol 2005; 6:197-208; PMID:15738986; http://dx.doi.org/10.1038/nrm1589

[30] Uversky VN, Dunker AK. Understanding protein nonfolding. Biochim Biophys Acta 2010; 1804:1231-64; PMID: 20117254; http://dx.doi.org/10.1016/j.bbapap.2010.01.017

[31] Uversky VN. The mysterious unfoldome: structureless, underappreciated, yet vital part of any given proteome. J Biomed Biotechnol 2010; 2010:568068; PMID:20011072; http://dx.doi.org/10.1155/2010/568068

[32] Dunker AK, Oldfield CJ, Meng J, Romero P, Yang JY, Chen JW, Vacic V, Obradovic Z, Uversky VN. The unfoldomics decade: an update on intrinsically disordered proteins. BMC Genomics 2008; 9 Suppl 2:S1; http://dx.doi.org/10.1186/1471-2164-9-S2-S1

[33] Dunker AK, Silman I, Uversky VN, Sussman JL. Function and structure of inherently disordered proteins. Curr Opin Struct Biol 2008; 18:756-64; PMID:18952168; http://dx.doi. org/10.1016/j.sbi.2008.10.002

[34] Dunker AK, Babu M, Barbar E, Blackledge M, Bondos SE, Dosztányi Z, Dyson HJ, Forman-Kay J, Fuxreiter M, Gsponer J, et al. What's in a name? Why these proteins are intrinsically disordered. Intrinsically Disordered Proteins 2013; 1:e24157; http://dx.doi.org/10.4161/idp.24157

[35] Dunker AK, Obradovic Z, Romero P, Garner EC, Brown CJ. Intrinsic protein disorder in complete genomes. Genome Inform Ser Workshop Genome Inform 2000; 11:161-71; PMID:11700597.

[36] Ward JJ, Sodhi JS, McGuffin LJ, Buxton BF, Jones DT. Prediction and functional analysis of native disorder in proteins from the three kingdoms of life. J Mol Biol 2004; 337:635-45; PMID:15019783; http://dx.doi.org/ 10.1016/j.jmb.2004.02.002

[37] Tokuriki N, Oldfield CJ, Uversky VN, Berezovsky IN, Tawfik DS. Do viral proteins possess unique biophysical features? Trends Biochem Sci 2009; 34:53-9; PMID:19062293; http://dx.doi.org/10.1016/j.tibs.2008.10.009

[38] Xue B, Williams RW, Oldfield CJ, Dunker AK, Uversky VN. Archaic chaos: intrinsically disordered proteins in Archaea. BMC Syst Biol 2010; 4 Suppl 1:S1; PMID: 20522251; http://dx.doi.org/10.1186/1752-0509-4-S1-S1
[39] Xue B, Dunker AK, Uversky VN. Orderly order in protein intrinsic disorder distribution: disorder in 3500 proteomes from viruses and the three domains of life. J Biomol Struct Dyn 2012; 30:137-49; PMID:22702725; http://dx.doi.org/10.1080/07391102.2012.675145

[40] Oldfield CJ, Cheng Y, Cortese MS, Brown CJ, Uversky VN, Dunker AK. Comparing and combining predictors of mostly disordered proteins. Biochemistry 2005; 44:19892000; PMID:15697224; http://dx.doi.org/10.1021/ bi047993o

[41] Xue B, Dunker AK, Uversky VN. Orderly order in protein intrinsic disorder distribution: Disorder in thirty five hundred proteomes from viruses and the three domains of life. J Biomol Struct Dyn 2012; 30(2):137-49; PMID: 22702725; http://dx.doi.org/10.1080/07391102.2012.675145

[42] Uversky VN. Protein folding revisited. A polypeptide chain at the folding-misfolding-nonfolding cross-roads: which way to go? Cell Mol Life Sci 2003; 60:1852-71; PMID:14523548; http://dx.doi.org/10.1007/s00018-0033096-6

[43] Turoverov KK, Kuznetsova IM, Uversky VN. The protein kingdom extended: ordered and intrinsically disordered proteins, their folding, supramolecular complex formation, and aggregation. Prog Biophys Mol Biol 2010; 102:73-84; PMID:20097220; http://dx.doi.org/ 10.1016/j.pbiomolbio.2010.01.003

[44] Dyson HJ. Expanding the proteome: disordered and alternatively folded proteins. Q Rev Biophys 2011; 44:467-518; PMID:21729349; http://dx.doi.org/10.1017/ S0033583511000060

[45] Tompa P. Intrinsically disordered proteins: a 10-year recap. Trends Biochem Sci 2012; 37:509-16; PMID:22989858; http://dx.doi.org/10.1016/j.tibs.2012.08.004

[46] Uversky VN. A decade and a half of protein intrinsic disorder: Biology still waits for physics. Protein Sci 2013; 22:693-724; PMID:23553817; http://dx.doi.org/ $10.1002 /$ pro. 2261

[47] Daughdrill GW, Pielak GJ, Uversky VN, Cortese MS, Dunker AK. Natively disordered proteins. In: Buchner J, Kiefhaber T, eds. Handbook of Protein Folding. Weinheim, Germany: Wiley-VCH, Verlag GmbH \& Co., 2005:271-353.

[48] Dunker AK, Brown CJ, Obradovic Z. Identification and functions of usefully disordered proteins. Adv Protein Chem 2002; 62:25-49; PMID:12418100; http://dx.doi. org/10.1016/S0065-3233(02)62004-2

[49] Dunker AK, Brown CJ, Lawson JD, Iakoucheva LM, Obradovic Z. Intrinsic disorder and protein function. Biochemistry 2002; 41:6573-82; PMID:12022860; http:// dx.doi.org/10.1021/bi012159+

[50] Dunker AK, Cortese MS, Romero P, Iakoucheva LM, Uversky VN. Flexible nets. The roles of intrinsic disorder in protein interaction networks. Febs J 2005; 272:5129-48; PMID:16218947; http://dx.doi.org/10.1111/j.1742-4658. 2005.04948.x

[51] Dunker AK, Garner E, Guilliot S, Romero P, Albrecht K, Hart J, Obradovic Z, Kissinger C, Villafranca JE. 
Protein disorder and the evolution of molecular recognition: theory, predictions and observations. Pac Symp Biocomput 1998:473-84; PMID:9697205.

[52] Tompa P. The interplay between structure and function in intrinsically unstructured proteins. FEBS Lett 2005; 579:3346-54; PMID:15943980; http://dx.doi.org/ 10.1016/j.febslet.2005.03.072

[53] Tompa P, Csermely P. The role of structural disorder in the function of RNA and protein chaperones. FASEB J 2004; 18:1169-75; PMID:15284216; http://dx.doi.org/ 10.1096/fj.04-1584rev

[54] Tompa P, Szasz C, Buday L. Structural disorder throws new light on moonlighting. Trends Biochem Sci 2005; 30:484-9; PMID:16054818; http://dx.doi.org/10.1016/j. tibs.2005.07.008

[55] Xie H, Vucetic S, Iakoucheva LM, Oldfield CJ, Dunker AK, Uversky VN, Obradovic Z. Functional anthology of intrinsic disorder. One. Biological processes and functions of proteins with long disordered regions. J Proteome Res 2007; 6:1882-98; PMID:17391014; http://dx. doi.org/10.1021/pr060392u

[56] Vucetic S, Xie H, Iakoucheva LM, Oldfield CJ, Dunker AK, Obradovic Z, Uversky VN. Functional anthology of intrinsic disorder. Two. Cellular components, domains, technical terms, developmental processes, and coding sequence diversities correlated with long disordered regions. J Proteome Res 2007; 6:1899-916; PMID: 17391015; http://dx.doi.org/10.1021/pr060393m

[57] Xie H, Vucetic S, Iakoucheva LM, Oldfield CJ, Dunker AK, Obradovic Z, Uversky VN. Functional anthology of intrinsic disorder. Three. Ligands, post-translational modifications, and diseases associated with intrinsically disordered proteins. J Proteome Res 2007; 6:1917-32; PMID:17391016; http://dx.doi.org/10.1021/pr060394e

[58] Uversky VN, Oldfield CJ, Dunker AK. Showing your ID: intrinsic disorder as an ID for recognition, regulation and cell signaling. J Mol Recognit 2005; 18:343-84; PMID:16094605; http://dx.doi.org/10.1002/jmr.747

[59] Uversky VN, Oldfield CJ, Dunker AK. Intrinsically disordered proteins in human diseases: introducing the D2 concept. Annu Rev Biophys 2008; 37:215-46; PMID: 18573080; http://dx.doi.org/10.1146/annurev.biophys. 37.032807.125924

[60] Uversky VN, Dave V, Iakoucheva LM, Malaney P, Metallo SJ, Pathak RR, Joerger AC. Pathological unfoldomics of uncontrolled chaos: intrinsically disordered proteins and human diseases. Chem Rev 2014; 114:6844-79; PMID:24830552; http://dx.doi.org/10.1021/cr400713r

[61] Cheng Y, LeGall T, Oldfield CJ, Dunker AK, Uversky VN. Abundance of intrinsic disorder in protein associated with cardiovascular disease. Biochemistry 2006; 45:10448-60; PMID:16939197; http://dx.doi.org/10.1021/bi060981d

[62] Romero P, Obradovic Z, Li X, Garner EC, Brown CJ, Dunker AK. Sequence complexity of disordered protein. Proteins 2001; 42:38-48; PMID:11093259; http://dx.doi. org/10.1002/1097-0134(20010101)42:1<38::AID-PROT $50>3.0 . \mathrm{CO} ; 2-3$
[63] Peng K, Vucetic S, Radivojac P, Brown CJ, Dunker AK, Obradovic Z. Optimizing long intrinsic disorder predictors with protein evolutionary information. J Bioinform Comput Biol 2005; 3:35-60; PMID:15751111; http://dx. doi.org/10.1142/S0219720005000886

[64] Peng K, Radivojac P, Vucetic S, Dunker AK, Obradovic Z. Length-dependent prediction of protein intrinsic disorder. BMC Bioinformatics 2006; 7:208; PMID: 16618368; http://dx.doi.org/10.1186/1471-2105-7-208

[65] Xue B, Dunbrack RL, Williams RW, Dunker AK, Uversky VN. PONDR-FIT: a meta-predictor of intrinsically disordered amino acids. Biochim Biophys Acta 2010; 1804:996-1010; PMID:20100603; http://dx.doi.org/ 10.1016/j.bbapap.2010.01.011

[66] Peng ZL, Kurgan L. Comprehensive comparative assessment of in-silico predictors of disordered regions. Curr Protein Pept Sci 2012; 13:6-18; PMID:22044149; http:// dx.doi.org/10.2174/138920312799277938

[67] Fan X, Kurgan L. Accurate prediction of disorder in protein chains with a comprehensive and empirically designed consensus. J Biomol Struct Dyn 2014; 32:448-64; PMID: 23534882; $\quad$ http://dx.doi.org/10.1080/07391102.2013. 775969

[68] Prilusky J, Felder CE, Zeev-Ben-Mordehai T, Rydberg EH, Man O, Beckmann JS, Silman I, Sussman JL. FoldIndex: a simple tool to predict whether a given protein sequence is intrinsically unfolded. Bioinformatics 2005; 21:3435-8; PMID:15955783; http://dx.doi.org/10.1093/ bioinformatics/bti537

[69] Dosztanyi Z, Csizmok V, Tompa P, Simon I. IUPred: web server for the prediction of intrinsically unstructured regions of proteins based on estimated energy content. Bioinformatics 2005; 21:3433-4; PMID:15955779; http://dx. doi.org/10.1093/bioinformatics/bti541

[70] Oates ME, Romero P, Ishida T, Ghalwash M, Mizianty MJ, Xue B, Dosztanyi Z, Uversky VN, Obradovic Z, Kurgan L, et al. D(2)P(2): database of disordered protein predictions. Nucleic Acids Res 2013; 41:D508-16; PMID:23203878; http://dx.doi.org/10.1093/nar/gks1226

[71] Obradovic Z, Peng K, Vucetic S, Radivojac P, Dunker AK. Exploiting heterogeneous sequence properties improves prediction of protein disorder. Proteins 2005; 61 Suppl 7:176-82; PMID:16187360; http://dx.doi.org/ 10.1002/prot.20735

[72] Peng K, Radivojac P, Vucetic S, Dunker AK, Obradovic Z. Length-dependent prediction of protein intrinsic disorder. Bmc Bioinformatics 2006; 7:208.

[73] Ishida T, Kinoshita K. PrDOS: prediction of disordered protein regions from amino acid sequence. Nucleic Acids Res 2007; 35:W460-4; PMID:17567614; http://dx. doi.org/10.1093/nar/gkm363

[74] Walsh I, Martin AJ, Di Domenico T, Tosatto SC. ESpritz: accurate and fast prediction of protein disorder. Bioinformatics 2012; 28:503-9; PMID:22190692; http:// dx.doi.org/10.1093/bioinformatics/btr682

[75] Szklarczyk D, Franceschini A, Kuhn M, Simonovic M, Roth A, Minguez P, Doerks T, Stark M, Muller J, Bork 
P, et al. The STRING database in 2011: functional interaction networks of proteins, globally integrated and scored. Nucleic Acids Res 2011; 39:D561-8; PMID: 21045058; http://dx.doi.org/10.1093/nar/gkq973

[76] Iakoucheva LM, Radivojac P, Brown CJ, O'Connor TR, Sikes JG, Obradovic Z, Dunker AK. The importance of intrinsic disorder for protein phosphorylation. Nucleic Acids Res 2004; 32:1037-49; PMID:14960716; http://dx. doi.org/10.1093/nar/gkh253

[77] Pejaver V, Hsu WL, Xin F, Dunker AK, Uversky VN, Radivojac P. The structural and functional signatures of proteins that undergo multiple events of post-translational modification. Protein Sci 2014; 23:1077-93; PMID:24888500; http://dx.doi.org/10.1002/pro.2494

[78] Shapiro L, Scherer PE. The crystal structure of a complement-1q family protein suggests an evolutionary link to tumor necrosis factor. Curr Biol 1998; 8:335-8; PMID:9512423; http://dx.doi.org/10.1016/S0960-9822 (98)70133-2

[79] Yokota T, Oritani K, Takahashi I, Ishikawa J, Matsuyama A, Ouchi N, Kihara S, Funahashi T, Tenner AJ, Tomiyama Y, et al. Adiponectin, a new member of the family of soluble defense collagens, negatively regulates the growth of myelomonocytic progenitors and the functions of macrophages. Blood 2000; 96:1723-32; PMID:10961870.

[80] Waki H, Yamauchi T, Kamon J, Ito Y, Uchida S, Kita S, Hara K, Hada Y, Vasseur F, Froguel P, et al. Impaired multimerization of human adiponectin mutants associated with diabetes. Molecular structure and multimer formation of adiponectin. J Biol Chem 2003; 278:4035263; PMID:12878598; http://dx.doi.org/10.1074/jbc. M300365200

[81] Schraw T, Wang ZV, Halberg N, Hawkins M, Scherer PE. Plasma adiponectin complexes have distinct biochemical characteristics. Endocrinol 2008; 149:2270-82; PMID:18202126; http://dx.doi.org/10.1210/en.2007-1561

[82] Takuwa A, Yoshida T, Maruno T, Kawahara K, Mochizuki M, Nishiuchi Y, Kobayashi Y, Ohkubo T. Ordered self-assembly of the collagenous domain of adiponectin with noncovalent interactions via glycosylated lysine residues. FEBS Lett 2016; 590:195-201; PMID: 26823167; http://dx.doi.org/10.1002/1873-3468.12034

[83] Tsao TS, Tomas E, Murrey HE, Hug C, Lee DH, Ruderman NB, Heuser JE, Lodish HF. Role of disulfide bonds in Acrp30/adiponectin structure and signaling specificity. Different oligomers activate different signal transduction pathways. J Biol Chem 2003; 278:50810-7; PMID:14522956; http://dx.doi.org/10.1074/jbc.M309469200

[84] Wang Y, Xu A, Knight C, Xu LY, Cooper GJ. Hydroxylation and glycosylation of the four conserved lysine residues in the collagenous domain of adiponectin. Potential role in the modulation of its insulin-sensitizing activity. J Biol Chem 2002; 277:19521-9; PMID:11912203; http://dx.doi. org/10.1074/jbc.M200601200

[85] Peysselon F, Xue B, Uversky VN, Ricard-Blum S. Intrinsic disorder of the extracellular matrix. Mol Biosyst
2011; 7:3353-65; PMID:22009114; http://dx.doi.org/ $10.1039 / \mathrm{c} 1 \mathrm{mb} 05316 \mathrm{~g}$

[86] Smithers B, Oates ME, Tompa P, Gough J. Three reasons protein disorder analysis makes more sense in the light of collagen. Protein Sci 2016; PMID:26941008; http://dx.doi.org/10.1002/pro.2913

[87] Li SH, Burns DK, Rumberger JM, Presky DH, Wilkinson VL, Anostario M, Jr, Wolitzky BA, Norton CR, Familletti PC, Kim KJ, et al. Consensus repeat domains of E-selectin enhance ligand binding. J Biol Chem 1994; 269:4431-7; PMID:7508442.

[88] Owens RM, Gu X, Shin M, Springer TA, Jin MM. Engineering of single Ig superfamily domain of intercellular adhesion molecule 1 (ICAM-1) for native fold and function. J Biol Chem 2010; 285:15906-15; PMID:20304924; http://dx.doi.org/10.1074/jbc.M110.104349

[89] Diamond MS, Staunton DE, Marlin SD, Springer TA. Binding of the integrin Mac-1 (CD11b/CD18) to the third immunoglobulin-like domain of ICAM-1 (CD54) and its regulation by glycosylation. Cell 1991; 65:961-71; PMID: 1675157; http://dx.doi.org/10.1016/0092-8674(91)90548-D

[90] Casasnovas JM, Stehle T, Liu JH, Wang JH, Springer TA. A dimeric crystal structure for the N-terminal two domains of intercellular adhesion molecule-1. Proc Natl Acad Sci U S A 1998; 95:4134-9; PMID:9539702; http:// dx.doi.org/10.1073/pnas.95.8.4134

[91] Jimenez D, Roda-Navarro P, Springer TA, Casasnovas JM. Contribution of $\mathrm{N}$-linked glycans to the conformation and function of intercellular adhesion molecules (ICAMs). J Biol Chem 2005; 280:5854-61; PMID:15545280; http://dx. doi.org/10.1074/jbc.M412104200

[92] Yang Y, Jun CD, Liu JH, Zhang R, Joachimiak A, Springer TA, Wang JH. Structural basis for dimerization of ICAM-1 on the cell surface. Mol Cell 2004; 14:26976; PMID:15099525; http://dx.doi.org/10.1016/S10972765(04)00204-7

[93] Romero PR, Zaidi S, Fang YY, Uversky VN, Radivojac P, Oldfield CJ, Cortese MS, Sickmeier M, LeGall T, Obradovic Z, et al. Alternative splicing in concert with protein intrinsic disorder enables increased functional diversity in multicellular organisms. Proc Natl Acad Sci U S A 2006; 103:8390-5; PMID:16717195; http://dx.doi. org/10.1073/pnas.0507916103

[94] Haffner SM, Lehto S, Ronnemaa T, Pyorala K, Laakso M. Mortality from coronary heart disease in subjects with type 2 diabetes and in nondiabetic subjects with and without prior myocardial infarction. N Engl J Med 1998; 339:229-34; PMID:9673301; http://dx.doi.org/ 10.1056/NEJM199807233390404

[95] Newman AB, Siscovick DS, Manolio TA, Polak J, Fried LP, Borhani NO, Wolfson SK. Ankle-arm index as a marker of atherosclerosis in the Cardiovascular Health Study. Cardiovascular Heart Study (CHS) Collaborative Research Group. Circulation 1993; 88:837-45; PMID:8353913; http://dx.doi. org/10.1161/01.CIR.88.3.837

[96] Wannamethee SG, Perry IJ, Shaper AG. Nonfasting serum glucose and insulin concentrations and the risk 
of stroke. Stroke 1999; 30:1780-6; PMID:10471423; http://dx.doi.org/10.1161/01.STR.30.9.1780

[97] Almdal T, Scharling H, Jensen JS, Vestergaard H. The independent effect of type 2 diabetes mellitus on ischemic heart disease, stroke, and death: a population-based study of 13,000 men and women with 20 years of follow-up. Arch Intern Med 2004; 164:1422-6; PMID:15249351; http://dx. doi.org/10.1001/archinte.164.13.1422

[98] Yki-Ja rvinen H. Prediction and prevention of noninsulin-dependent diabetes mellitus. In: Williams G, Pickup J, eds. Textbook of Diabetes. Oxford: Blackwell, 2001; 83:1-13.

[99] Steinberg HO, Chaker H, Leaming R, Johnson A, Brechtel $\mathrm{G}$, Baron $\mathrm{AD}$. Obesity/insulin resistance is associated with endothelial dysfunction. Implications for the syndrome of insulin resistance. J Clin Invest 1996; 97:2601-10; PMID:8647954; http://dx.doi.org/10.1172/JCI118709

[100] Al Suwaidi J, Higano ST, Holmes DR, Jr, Lennon R, Lerman A. Obesity is independently associated with coronary endothelial dysfunction in patients with normal or mildly diseased coronary arteries. J Am Coll Cardiol 2001; 37:1523-8; PMID:11345360; http://dx.doi.org/ 10.1016/S0735-1097(01)01212-8

[101] Kim DH, Vanella L, Inoue K, Burgess A, Gotlinger K, Manthati VL, Koduru SR, Zeldin DC, Falck JR, Schwartzman ML, et al. Epoxyeicosatrienoic acid agonist regulates human mesenchymal stem cell-derived adipocytes through activation of HO-1-pAKT signaling and a decrease in PPARgamma. Stem Cells Dev 2010; 19:1863-73; PMID:20412023; http://dx.doi.org/10.1089/ scd.2010.0098

[102] Shibata R, Sato K, Pimentel DR, Takemura Y, Kihara S, Ohashi K, Funahashi T, Ouchi N, Walsh K. Adiponectin protects against myocardial ischemia-reperfusion injury through AMPK- and COX-2-dependent mechanisms. Nat Med 2005; 11:1096-103; PMID:16155579; http://dx. doi.org/10.1038/nm1295

[103] Meigs JB, Hu FB, Rifai N, Manson JE. Biomarkers of endothelial dysfunction and risk of type 2 diabetes mellitus. JAMA 2004; 291:1978-86; PMID:15113816; http:// dx.doi.org/10.1001/jama.291.16.1978

[104] Thorand B, Baumert J, Chambless L, Meisinger C, Kolb $\mathrm{H}$, Doring A, Lowel H, Koenig W. Elevated markers of endothelial dysfunction predict type 2 diabetes mellitus in middle-aged men and women from the general population. Arterioscler Thromb Vasc Biol 2006; 26:398-405; PMID:16322530; http://dx.doi.org/10.1161/01. ATV.0000198392.05307.aa

[105] Song Y, Manson JE, Tinker L, Rifai N, Cook NR, Hu FB, Hotamisligil GS, Ridker PM, Rodriguez BL, Margolis $\mathrm{KL}$, et al. Circulating levels of endothelial adhesion molecules and risk of diabetes in an ethnically diverse cohort of women. Diabetes 2007; 56:1898-904; PMID:17389327; http://dx.doi.org/10.2337/db07-0250

[106] Laaksonen DE, Niskanen L, Nyyssonen K, Punnonen K, Tuomainen TP, Valkonen VP, Salonen R, Salonen JT. $\mathrm{C}$-reactive protein and the development of the metabolic syndrome and diabetes in middle-aged men. Diabetologia 2004; 47:1403-10; PMID:15309290; http:// dx.doi.org/10.1007/s00125-004-1472-x

[107] Ingelsson E, Hulthe J, Lind L. Inflammatory markers in relation to insulin resistance and the metabolic syndrome. Eur J Clin Invest 2008; 38:502-9; PMID:18489581; http:// dx.doi.org/10.1111/j.1365-2362.2008.01962.x

[108] Hajer GR, van Haeften TW, Visseren FL. Adipose tissue dysfunction in obesity, diabetes, and vascular diseases. Eur Heart J 2008; 29:2959-71; PMID:18775919; http:// dx.doi.org/10.1093/eurheartj/ehn387

[109] Matsuzawa Y. Establishment of a concept of visceral fat syndrome and discovery of adiponectin. Proc Jpn Acad Ser B Phys Biol Sci 2010; 86:131-41; PMID:20154470; http://dx.doi.org/10.2183/pjab.86.131

[110] Rui L, Aguirre V, Kim JK, Shulman GI, Lee A, Corbould A, Dunaif A, White MF. Insulin/IGF-1 and TNF- $\alpha$ stimulate phosphorylation of IRS-1 at inhibitory Ser307 via distinct pathways. J Clin Invest 2001; 107:181-9; PMID:11160134; http://dx.doi.org/10.1172/JCI10934

[111] Fernandez-Veledo S, Vila-Bedmar R, Nieto-Vazquez I, Lorenzo M. c-Jun N-terminal kinase $1 / 2$ activation by tumor necrosis factor- $\alpha$ induces insulin resistance in human visceral but not subcutaneous adipocytes: reversal by liver X receptor agonists. J Clin Endocrinol Metab 2009; 94:3583-93; PMID:19567513; http://dx.doi.org/ 10.1210/jc.2009-0558

[112] Vaverkova H, Karasek D, Novotny D, Kovarova D, Halenka M, Slavik L, Frohlich J. Positive association of adiponectin with soluble thrombomodulin, von Willebrand factor and soluble VCAM-1 in dyslipidemic subjects. Clin Biochem 2013; 46:766-71; PMID:23499586; http://dx.doi.org/10.1016/j.clinbiochem.2013.02.014

[113] Vaverkova H, Karasek D, Novotny D, Jackuliakova D, Halenka M, Lukes J, Frohlich J. Positive association of adiponectin with soluble vascular cell adhesion molecule sVCAM-1 levels in patients with vascular disease or dyslipidemia. Atherosclerosis 2008; 197:725-31; PMID:17714716; http://dx.doi.org/10.1016/j. atherosclerosis.2007.07.005

[114] Ran J, Xiong X, Liu W, Guo S, Li Q, Zhang R, Lao G. Increased plasma adiponectin closely associates with vascular endothelial dysfunction in type 2 diabetic patients with diabetic nephropathy. Diabetes Res Clin Pract 2010; 88:177-83; PMID:20138682; http://dx.doi. org/10.1016/j.diabres.2010.01.021

[115] Shinozaki K, Hirayama A, Nishio Y, Yoshida Y, Ohtani T, Okamura T, Masada M, Kikkawa R, Kodama K, Kashiwagi A. Coronary endothelial dysfunction in the insulin-resistant state is linked to abnormal pteridine metabolism and vascular oxidative stress. J Am Coll Cardiol 2001; 38:1821-8; PMID:11738280; http://dx.doi. org/10.1016/S0735-1097(01)01659-X

[116] Scherrer U, Randin D, Vollenweider P, Vollenweider L, Nicod P. Nitric oxide release accounts for insulin's vascular effects in humans. J Clin Invest 1994; 94:2511-5; PMID:7989610; http://dx.doi.org/10.1172/JCI117621 
[117] Steinberg HO, Brechtel G, Johnson A, Fineberg N, Baron AD. Insulin-mediated skeletal muscle vasodilation is nitric oxide dependent. A novel action of insulin to increase nitric oxide release. J Clin Invest 1994; 94:1172-9; PMID:8083357; http://dx.doi.org/10.1172/ JCI117433

[118] Williams SB, Cusco JA, Roddy MA, Johnstone MT, Creager MA. Impaired nitric oxide-mediated vasodilation in patients with non-insulin-dependent diabetes mellitus. J Am Coll Cardiol 1996; 27:567-74; PMID:8606266; http://dx.doi.org/10.1016/0735-1097(95)00522-6

[119] Baron AD, Steinberg HO, Chaker H, Leaming R, Johnson A, Brechtel G. Insulin-mediated skeletal muscle vasodilation contributes to both insulin sensitivity and responsiveness in lean humans. J Clin Invest 1995; 96:786-92; PMID:7635973; http://dx.doi.org/10.1172/ JCI118124

[120] Malmstrom R, Packard CJ, Caslake M, Bedford D, Stewart P, Yki-Jarvinen H, Shepherd J, Taskinen MR. Defective regulation of triglyceride metabolism by insulin in the liver in NIDDM. Diabetologia 1997; 40:454-62; PMID:9112023; http://dx.doi.org/10.1007/s001250050700

[121] Makimattila S, Liu ML, Vakkilainen J, Schlenzka A, Lahdenpera S, Syvanne M, Mantysaari M, Summanen $\mathrm{P}$, Bergholm R, Taskinen MR, et al. Impaired endothelium-dependent vasodilation in type 2 diabetes. Relation to LDL size, oxidized LDL, and antioxidants. Diabetes Care 1999; 22:973-81; PMID:10372251; http://dx.doi. org/10.2337/diacare.22.6.973

[122] Dresner A, Laurent D, Marcucci M, Griffin ME, Dufour S, Cline GW, Slezak LA, Andersen DK, Hundal RS, Rothman DL, et al. Effects of free fatty acids on glucose transport and IRS-1-associated phosphatidylinositol 3kinase activity. J Clin Invest 1999; 103:253-9; PMID: 9916137; http://dx.doi.org/10.1172/JCI5001

[123] Griffin ME, Marcucci MJ, Cline GW, Bell K, Barucci N, Lee D, Goodyear LJ, Kraegen EW, White MF, Shulman GI. Free fatty acid-induced insulin resistance is associated with activation of protein kinase $\mathrm{C}$ theta and alterations in the insulin signaling cascade. Diabetes 1999; 48:1270-4; PMID:10342815; http://dx.doi.org/10.2337/ diabetes.48.6.1270

[124] Sheng T, Yang K. Adiponectin and its association with insulin resistance and type 2 diabetes. J Genet Genomics 2008; 35:321-6; PMID:18571119; http://dx.doi.org/ 10.1016/S1673-8527(08)60047-8

[125] Takeda Y, Nakanishi K, Tachibana I, Kumanogoh A. Adiponectin: a novel link between adipocytes and COPD. Vitamins Hormones 2012; 90:419-35; PMID:23017725; http:// dx.doi.org/10.1016/B978-0-12-398313-8.00016-6

[126] Lau WB, Tao L, Wang Y, Li R, Ma XL. Systemic adiponectin malfunction as a risk factor for cardiovascular disease. Antioxidants Redox Signal 2011; 15:1863-73; PMID: 21091079; http://dx.doi.org/10.1089/ars.2010.3743

[127] Goldstein BJ, Scalia RG, Ma XL. Protective vascular and myocardial effects of adiponectin. Nat Clin Practice
Cardiovascular Med 2009; 6:27-35; PMID:19029992; http://dx.doi.org/10.1038/ncpcardio1398

[128] Pietruczuk M, Pietruczuk A, Pancewicz S, Hermanowska-Szpakowicz T. [ICAM-1: structure, biological role and clinical significance]. Polski Merkur Lekarski 2004; 17:507-11; PMID:15754645.

[129] Abraham G, Colonno RJ. Many rhinovirus serotypes share the same cellular receptor. J Virol 1984; 51:340-5; PMID:6086949.

[130] Bella J, Kolatkar PR, Marlor CW, Greve JM, Rossmann MG. The structure of the two amino-terminal domains of human ICAM-1 suggests how it functions as a rhinovirus receptor and as an LFA-1 integrin ligand. Proc Natl Acad Sci U S A 1998; 95:4140-5; PMID:9539703; http://dx.doi.org/10.1073/pnas.95.8.4140

[131] Etienne-Manneville S, Chaverot N, Strosberg AD, Couraud PO. ICAM-1-coupled signaling pathways in astrocytes converge to cyclic AMP response element-binding protein phosphorylation and TNF- $\alpha$ secretion. J Immunol 1999; 163:668-74.

[132] Xiao X, Mruk DD, Cheng CY. Intercellular adhesion molecules (ICAMs) and spermatogenesis. Hum Reprod Update 2013; 19:167-86; PMID:23287428; http://dx.doi. org/10.1093/humupd/dms049

[133] Petruzzelli L, Takami M, Humes HD. Structure and function of cell adhesion molecules. Am J Med 1999; 106:467-76; PMID:10225251; http://dx.doi.org/10.1016/ S0002-9343(99)00058-3

[134] Wu TC. The role of vascular cell adhesion molecule-1 in tumor immune evasion. Cancer Res 2007; 67:6003-6; PMID:17616653; http://dx.doi.org/10.1158/0008-5472. CAN-07-1543

[135] Robbins SL, Cotran RS, Kumar V, Collins T. Robbins pathologic basis of disease. Philadelphia: WB Saunders, 1999.

[136] Hession C, Osborn L, Goff D, Chi-Rosso G, Vassallo C, Pasek M, Pittack C, Tizard R, Goelz S, McCarthy K, et al. Endothelial leukocyte adhesion molecule 1: direct expression cloning and functional interactions. Proc Natl Acad Sci USA 1990; 87:1673-7; PMID:1689848; http://dx.doi.org/10.1073/pnas.87.5.1673

[137] Bateman A, Coin L, Durbin R, Finn RD, Hollich V, Griffiths-Jones S, Khanna A, Marshall M, Moxon S, Sonnhammer EL, et al. The Pfam protein families database. Nucleic Acids Res 2004; 32:D138-41; PMID: 14681378; http://dx.doi.org/10.1093/nar/gkh121

[138] Finn RD, Mistry J, Schuster-Bockler B, Griffiths-Jones S, Hollich V, Lassmann T, Moxon S, Marshall M, Khanna A, Durbin R, et al. Pfam: clans, web tools and services. Nucleic Acids Res 2006; 34:D247-51; PMID:16381856; http://dx.doi.org/10.1093/nar/gkj149

[139] Finn RD, Tate J, Mistry J, Coggill PC, Sammut SJ, Hotz HR, Ceric G, Forslund K, Eddy SR, Sonnhammer EL, et al. The Pfam protein families database. Nucleic Acids Res 2008; 36:D281-8; PMID:18039703; http://dx.doi. org/10.1093/nar/gkm960 